\title{
Two new Bifurcia species (Aranei: Linyphiidae: Micronetinae) from Far East Russia
}

\author{
Ава новых вида Bifurcia (Aranei: Linyphiidae: Micronetinae) \\ с Аальнего Востока России
}

\section{Yuri M. Marusik ${ }^{1}$, Mikhail M. Omelko, ${ }^{2,3}$, Seppo Koponen ${ }^{4}$ Ю.М. Марусик ${ }^{1}$, М.М. Омелько ${ }^{2,3}$, С. Копонен ${ }^{4}$}

\footnotetext{
${ }^{1}$ Institute for Biological Problems of the North, Portovaya Street 18, Magadan 685000, Russia. E-mail: yurmar@mail.ru

${ }^{2}$ Gornotaezhnaya Station FEB RAS, Gornotaezhnoe Vil., Ussuriyski Dist., Primorski krai 692533, Russia. E-mail: omelkom@gmail.com

${ }^{3}$ Far Eastern Federal University, Sukhanova 8, Vladivostok 690950, Russia

${ }^{4}$ Zoological Museum, University of Turku, FI-20014 Turku, Finland. E-mail: sepkopo@utu.fi

${ }^{1}$ Институт Биологических проблем Севера ДВО РАН, ул. Портовая 18, Магадан 685000, Россия.

${ }^{2}$ Горнотаёжная станция ДВО РАН, с. Горнотаёжное, Уссурийский район, Приморский край, 692533, Россия.

3 Дальневосточный Федеральный Университет, ул. Суханова 8, Владивосток, 690950, Россия.
}

KEY WORDS: spiders, Araneae, Asia, Arcuphantes, new combination.

КЛЮЧЕВЫЕ СЛОВА: пауки, Araneae, Азия, Arcuphantes, новая комбинация.

ABSTRACT: Two new species of Bifurcia Saaristo, $\mathrm{Tu}$ et $\mathrm{Li}, 2006$ are described based on both sexes from the Maritime Province of Russia: B. oligerae sp.n. and B. tanasevitchi sp.n. Arcuphantes maritimus Tanasevitch, 2010 is transferred to Bifurcia, and a new combination is established: Bifurcia maritima (Tanasevitch, 2010), comb.n.

РЕЗЮМЕ: Описано два новых вида по обоим полам рода Bifurcia Saaristo, Tu et Li, 2006 из Приморья: B. oligerae sp.n. и B. tanasevitchi sp.n. Arcuphantes maritimus Tanasevitch, 2010 перенесен в род Bifurcia и установлена новая комбинация для Bifurcia maritima (Tanasevitch, 2010), comb.n.

\section{Introduction}

Three genera of Micronetinae, Arcuphantes Chamberlin et Ivie, 1943, Bifurcia Saaristo, Tu et Li, 2006 and Fusciphantes Oi, 1960 form a group with a long to very long epigynal scape. These spiders are distributed in the Western Nearctic and Far East Asia (NE China, Korea, Japan and Maritime Province of Russia). Most of the species belong to Arcuphantes (46). The two latter genera encompass five and eight species, respectively. The monophyly of this group has never been tested, and the Nearctic species have never been revised. By contrast, East Asian Arcuphantes are relatively well studied due to numerous publications of Chinese, Japanese and Korean Linyphiidae (cf. WSC, 2016). Saaristo et al. [2006] resurrected the Asian Fusciphantes, previously considered a junior synonym of Arcuphantes, and described the new genus Bifurcia. Tanasevitch [2010] doubted the validity of Fusciph- antes and Bifurcia; however, he did not synonymize the three genera. While studying material from the Maritime Province, we found two species belonging to the Arcuphantes group. The goal of this paper is to describe the new species.

\section{Material and methods}

Photographs were taken in dishes of different sizes with paraffin at the bottom. Specimens were photographed using a Canon 7D camera attached to an Olympus SZX16 stereomicroscope and with a SEM JEOL JSM-5200 scanning microscope at the Zoological Museum, University of Turku. Digital images were prepared using "CombineZP" and Zerene Stacker image stacking software. All measurements are given in millimetres $(\mathrm{mm})$. Abbreviations: $\mathrm{d}$ - dorsal, $\mathrm{p}$ - prolateral, $\mathrm{r}$ - retrolateral. Specimens treated here will be deposited in the Zoological Museum of Moscow State University (ZMMU) and the Manchester Museum of the University of Manchester. The terminology used in this work follows Tanasevitch (2010).

\section{Species survey}

\section{Bifurcia oligerae sp.n.}

Figs 1-3, 6-9, 11-13, 23-25.

MATERIAL. Holotype + (ZMMU), Russia, Maritime Province, Shkotovo Distr., env. of Anisimovka Vill., scree among coniferous forest near stream, $43^{\circ} 11^{\prime} \mathrm{N} 132^{\circ} 43^{\prime} \mathrm{E}, 22.06 .2015$ (M.M. Omelko). Paratypes: RUSSIA, Maritime Province.: $10^{7}, 8$ 우, 1 subad. O' (ZMMU), Lazovskii Dist., Lazo Reserve, Syao-Changou Gorge, mountain slope, debris under stones, 13.08.1981 (T.I. Oliger); 3 우 (MMUM), same reserve, Taningou Gorge, litter in alder-tree 

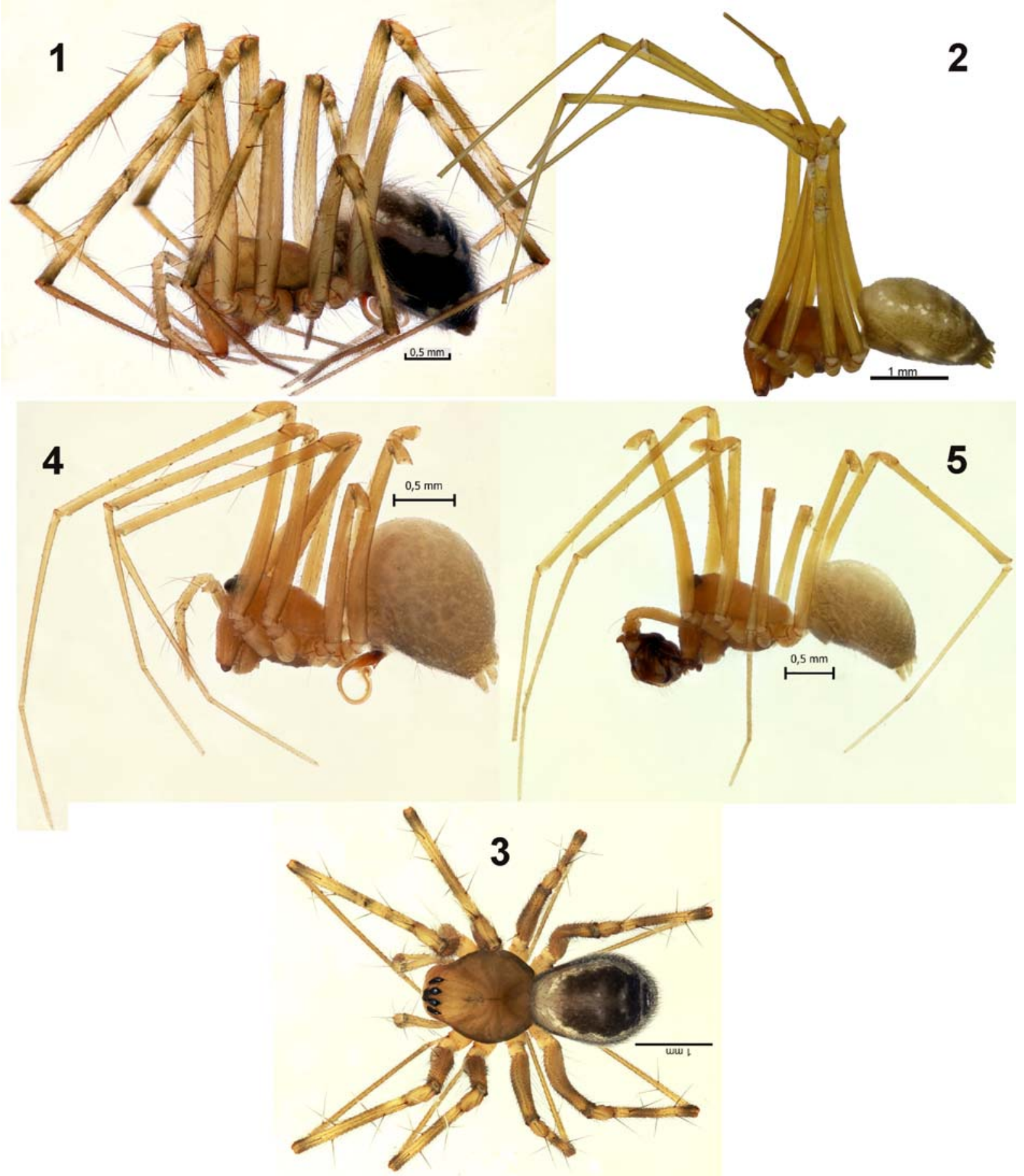

Figs 1-5. Habitus of Bifurcia oligerae sp.n. (1-3) and B. tanasevitchi sp.n. (4-5): 1, 4 - male, lateral; 2, 5 - female, lateral; 3 female, dorsal.

Рис. 1-5. Внешний вид Bifurcia oligerae sp.n. (1-3) и B. tanasevitchi sp.n. (4-5): 1, 4 - самец, сбоку; 2, 5 - самка, сбоку; 3 самка, сверху.

forest, 10.09.1980 (T.I. Oliger); $1 \sigma^{\top}$, Sukhoi Klyuch Gorge, open scree on south slope, upper part, under stones, 22.06.1981 (T.I. Oliger); 11 +o 1 subad. + (ZMMU), ShkotovoDistr., env. of Anisi-

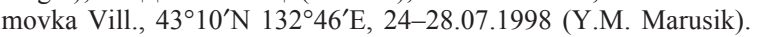

ETYMOLOGY. The species is named after Dr. Tatyana I. Oliger who has made important contributions to the study of spiders of the Maritime Province. 

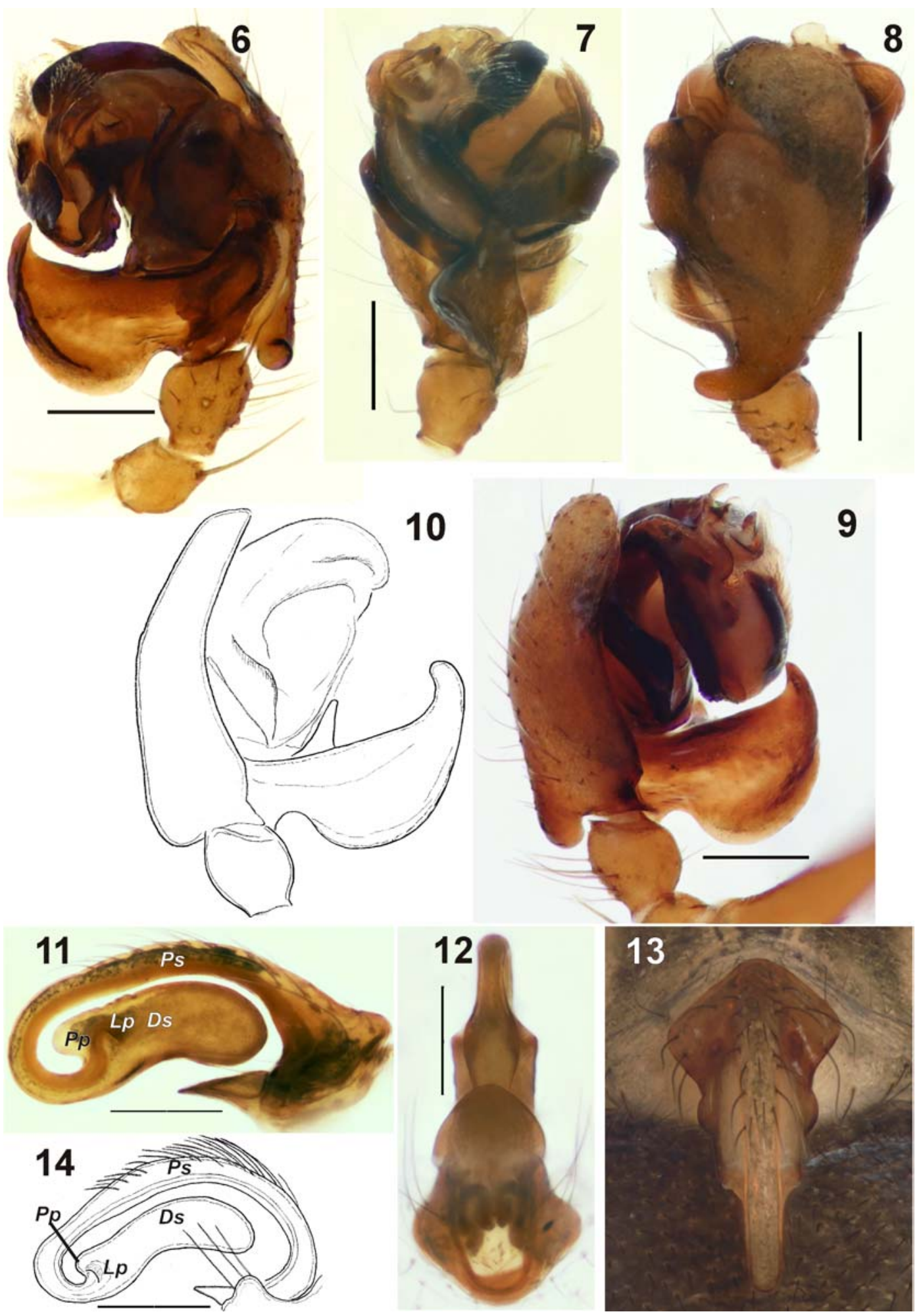

Figs 6-14. Copulatory organs of Bifurcia oligerae sp.n. $(6-9,11-13)$ and B. maritima $(10,14)$ : 6-8 - male palp, retrolateral, ventral and dorsal; 9-10 - male palp, prolateral. 11, 14 - epigyne, lateral; 12-13 - same, dorsal and ventral. 10, 14 - after Tanasevitch (2010) with modifications. Scale $=0.2 \mathrm{~mm}$. Abbreviations: $D s$ - distal part of scape; $L p$ - lateral pocket; $P p$ - posterior projection, $P s-$ proximal part of scape.

Рис. 6-14. Копулятивные органы Bifurcia oligerae sp.n. $(6-9,11-13)$ и B. maritima $(10,14)$ : 6-8 - пальпа самца, ретролатерально, вентрально и дорзально; 9-10 — пальпа самца, пролатерально. 11, 14 - эпигина, латерально; 12-13 — то же, дорзально и вентрально. 10, 14 - по Tanasevitch (2010) с изменениями. Масштаб 0,2 мм. 


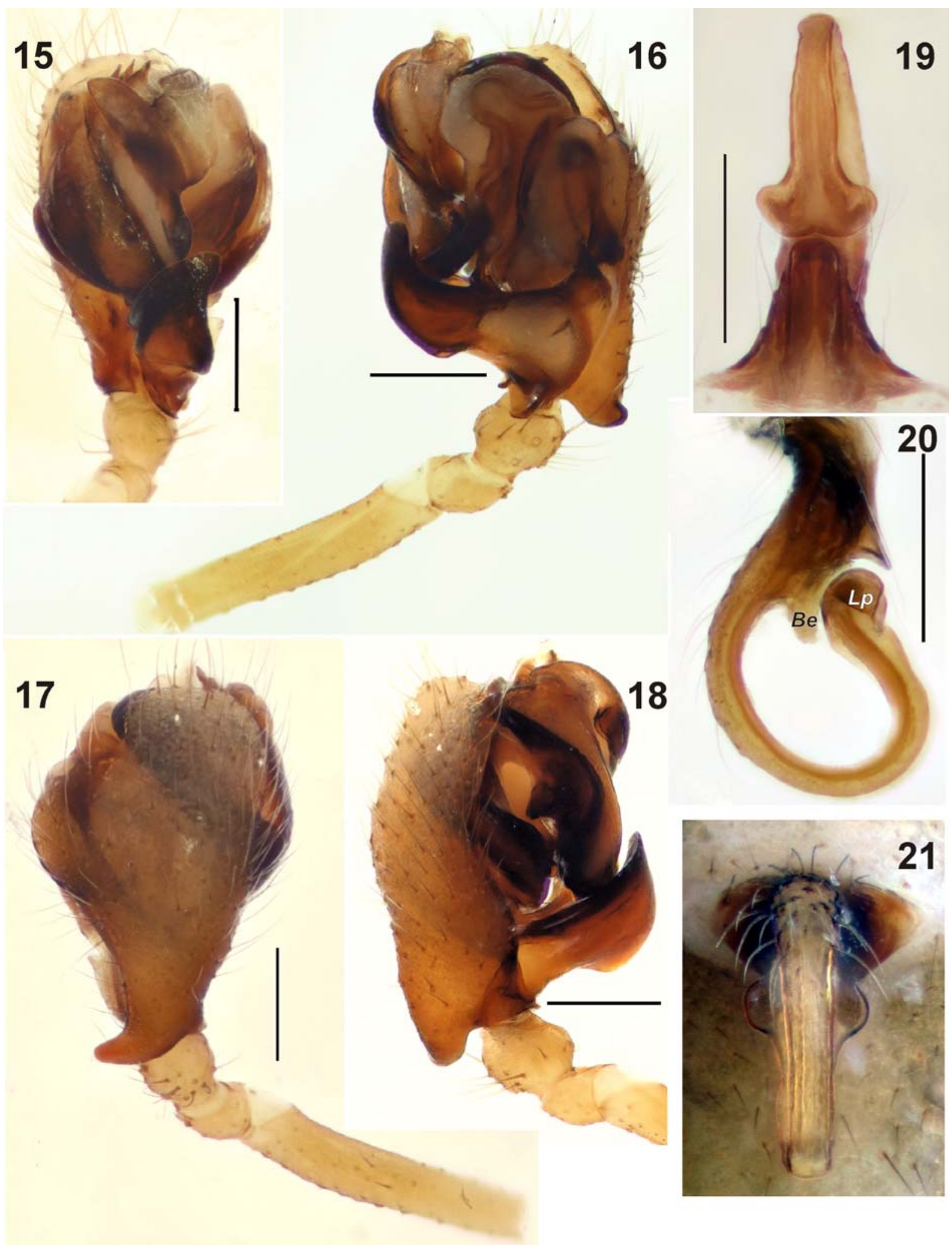

Figs 15-21. Copulatory organs of Bifurcia tanasevitchi sp.n.: 15 - male palp, ventral; 16 - same, retrolateral; 17 - same, dorsal; 18 - same, prolateral; $19-21$ - ventral, lateral and dorsal. Scale $=0.2 \mathrm{~mm}$. Abbreviations: $B e-$ basal extensioon of scape; $L p-$ lateral pocket.

Рис. 15-21. Копулятивные органы Bifurcia tanasevitchi sp.n.: 15 - пальпа самца, вентрально; 16 - то же, ретролатерально; 17 - то же, дорзально; 18 - то же, пролатерально; 19-21 - вентрально, латерально и дорзально. Масштаб 0,2 мм. 
DIAGNOSIS. The new species is easily differentiated from the sibling $B$. maritima by a wider paracymbium (Figs 9-10), oval "cirque-like" pocket of paracymbium (Figs 6, 22) (semicircular "cirque-like" pocket of cymbium in B. maritima), a wider distal part of the scape (length width ratio 2.9 in the new species and 3.94 in $B$. maritima, Figs 11, 14) and a longer posterior extension $(\mathrm{Se})$ of the distal part of the scape (Figs 11-14).

NOTE. The female was chosen as the holotype because it is more clearly differentiated from the sibling B. maritima. Trichobothria on metatarsi I-III are difficult to observe. Specimens collected by Oliger are in poor condition, and most of the spines and some leg segments are missing.

DESCRIPTION. Male (paratype). Total length 3.13, carapace 1.5 long, 1.13 wide. Carapace light brown with faintly visible radial stripes. Chelicerae, maxillae, labium and sternum light brown. Abdomen greyish without any pattern. TmI 0.23 .

Leg segment length of male:

\begin{tabular}{|l|c|c|c|c|c|}
\hline & Femur & Patella & Tibia & Metatarsus & Tarsus \\
\hline I & 2.63 & 0.43 & 2.75 & 2.80 & - \\
\hline II & 2.70 & 0.43 & 2.50 & 2.38 & - \\
\hline III & 1.93 & 0.43 & 1.75 & 1.78 & - \\
\hline IV & 2.58 & - & - & - & - \\
\hline
\end{tabular}

Palp as in Figs 6-9, 22-25. Cymbium with proximal hook-shaped apophysis $(\mathrm{Ce})$, paracymbium wide with small finger-like anterior extension $(P d)$ and elongate (oval) "cirque-like" pocket in basal part. Embolic division with a set of complex apophyses and lacks lamella characteristica. Lamellar extension of pseudolamella $(L e)$ barbed.

Female (paratype). Total length 3.15 , carapace 1.5 long, 1.15 wide. Carapace yellowish with dark edges. Chelicerae and maxillae brown. Labium and sternum dark grey. Legs yellowish with dark rings. Abdomen dark grey with pattern consisting of white lines and spots.

Chaetotaxy: Fe I-III 1d; patella I-IV 1d; tibia I-II 2d, 1p, 1r, 2v, III 2d, 1p, 1r, 1v, IV 2d, 1p, 1r; metatarsus I-IV 1d, 1p, 1r. Femur III has either 1 or no dorsal spines. TmI 0.17 .

Epigyne as in Figs 11-13. Scape very long, almost as long as postgastral part of abdomen; distal part of scape $(D s)$ wide, twice as wide as proximal $(P S)$ part; distal part of scape with posterior projection $(P p)$ behind lateral pocket $(L p)$.

Leg segment length of female:

\begin{tabular}{|l|c|c|c|c|c|c|}
\hline & Femur & Patella & Tibia & Metatarsus & Tarsus & Total \\
\hline I & 2.35 & 0.48 & 2.60 & 2.55 & 1.48 & 9.45 \\
\hline II & 2.48 & 0.48 & 2.43 & 2.38 & 1.25 & 9.00 \\
\hline III & 2.00 & 0.43 & 1.70 & 1.75 & 0.88 & 6.75 \\
\hline IV & 2.55 & 0.43 & 2.33 & 2.30 & 1.13 & 8.73 \\
\hline
\end{tabular}

Spination of female legs:

\begin{tabular}{|l|c|c|l|l|}
\hline & Femur & Patella & Tibia & Metatarsus \\
\hline I & $1 \mathrm{p}$ & 1d & $2 \mathrm{~d}, 1 \mathrm{p}, 1 \mathrm{r}, 2 \mathrm{v}$ & $1 \mathrm{~d}, 1 \mathrm{p}, 1 \mathrm{r}$ \\
\hline II & $1 \mathrm{p}$ & $1 \mathrm{~d}$ & $2 \mathrm{~d}, 1 \mathrm{p}, 1 \mathrm{r}, 2 \mathrm{v}$ & $1 \mathrm{~d}, 1 \mathrm{p}, 1 \mathrm{r}$ \\
\hline III & $1 \mathrm{(0)d}$ & $1 \mathrm{~d}$ & $2 \mathrm{~d}, 1 \mathrm{p}, 1 \mathrm{r}, 1 \mathrm{v}$ & $1 \mathrm{~d}, 1 \mathrm{p}, 1 \mathrm{r}$ \\
\hline IV & & 1d & $2 \mathrm{~d}, 1 \mathrm{p}, 1 \mathrm{r}$, & $1 \mathrm{~d}, 1 \mathrm{p}, 1 \mathrm{r}$ \\
\hline
\end{tabular}

DISTRIBUTION AND BIOLOGY. This species is known from the south part of the Maritime Province, particularly from the Lazo and Shkotovo districts. It inhabits stony screes, and in the Lazo Reserve it was found in the same scree with B. tanasevitchi sp.n.

\section{Bifurcia tanasevitchi sp.n.}

Figs 4-5, 15-21, 26-29.

MATERIAL. Holotype + (ZMMU), Russia, Maritime Province, Lazovskii Distr., Sukhoi Klyuch Gorge, closed scree in oak forest, south slope, 21.06.1981 (T.I. Oliger). Paratypes: RUSSIA, Maritime Province, Lazovskii Distr., Lazo Reserve: 1 ( (ZMMU), Syao-Changou Gorge, debris under stone, mountain slope, 13.08.1981 (T.I. Oliger); $10^{7}, 2$ 우 (MMUM), Sukhoi Klyuch Gorge, scree on south slope, 21.06.1981 (T.I. Oliger); $4 \mathrm{O}^{7} \mathrm{O}^{7}, 19$ 우 (ZMMU), same place, scree in oak forest, under stones, 21.06.1981 (T.I. Oliger).

NOTE. The female was chosen as the holotype because it is more clearly differentiated from other congeners. All specimens are old and have lost almost all hairs and spines, including trichobothria. Many specimens have lost some leg segments.

ETYMOLOGY. The species name is a patronym in honour of Dr. Andrei V. Tanasevitch, the leading world expert of Linyphiidae, on the occasion of his 60th birthday, the 8th of August, 2016.

DIAGNOSIS. The new species is easily differentiated from the other two congeners in the Maritime Province, $B$. oligerae sp.n. and B. maritima, by its smaller size (carapace no longer than $1.0 \mathrm{~mm}$ in $B$. tanasevitch $i$ sp.n., whereas in the two other species it is longer than $1.0 \mathrm{~mm}$ ), lack of abdominal pattern (well-developed in other species) and the shape of the copulatory organs. The female of $B$. tanasevitchi sp.n. has a nearly round scape (longer than high in the two other species) and lateral pockets on the end of the scape near the base of the epigyne (located in the mid-part of the scape on the posterior part of epigyne in the two other species). The male of B. tanasevitchi sp.n. differs from its congeners by having a triangular "cirque-like" pocket of paracymbium (semicircular or elongate-semicircular in other species) and having a paracymbial posterior extension $(\mathrm{Pe})$.

DESCRIPTION. Male. Total length 2.4, carapace 1.0 long, 0.85 wide. Carapace and abdomen uniformly coloured and lack any pattern (Fig. 5). MtI ca 0.18.

Leg segment length of male:

\begin{tabular}{|l|c|c|c|c|c|c|}
\hline & Femur & Patella & Tibia & Metatarsus & Tarsus & Total \\
\hline I & 1.88 & 0.30 & 2.10 & 1.75 & 1.03 & 7.05 \\
\hline II & 1.65 & 0.30 & 1.78 & - & - & - \\
\hline III & 1.30 & 0.25 & - & - & - & - \\
\hline IV & 1.75 & 0.25 & - & - & - & - \\
\hline
\end{tabular}




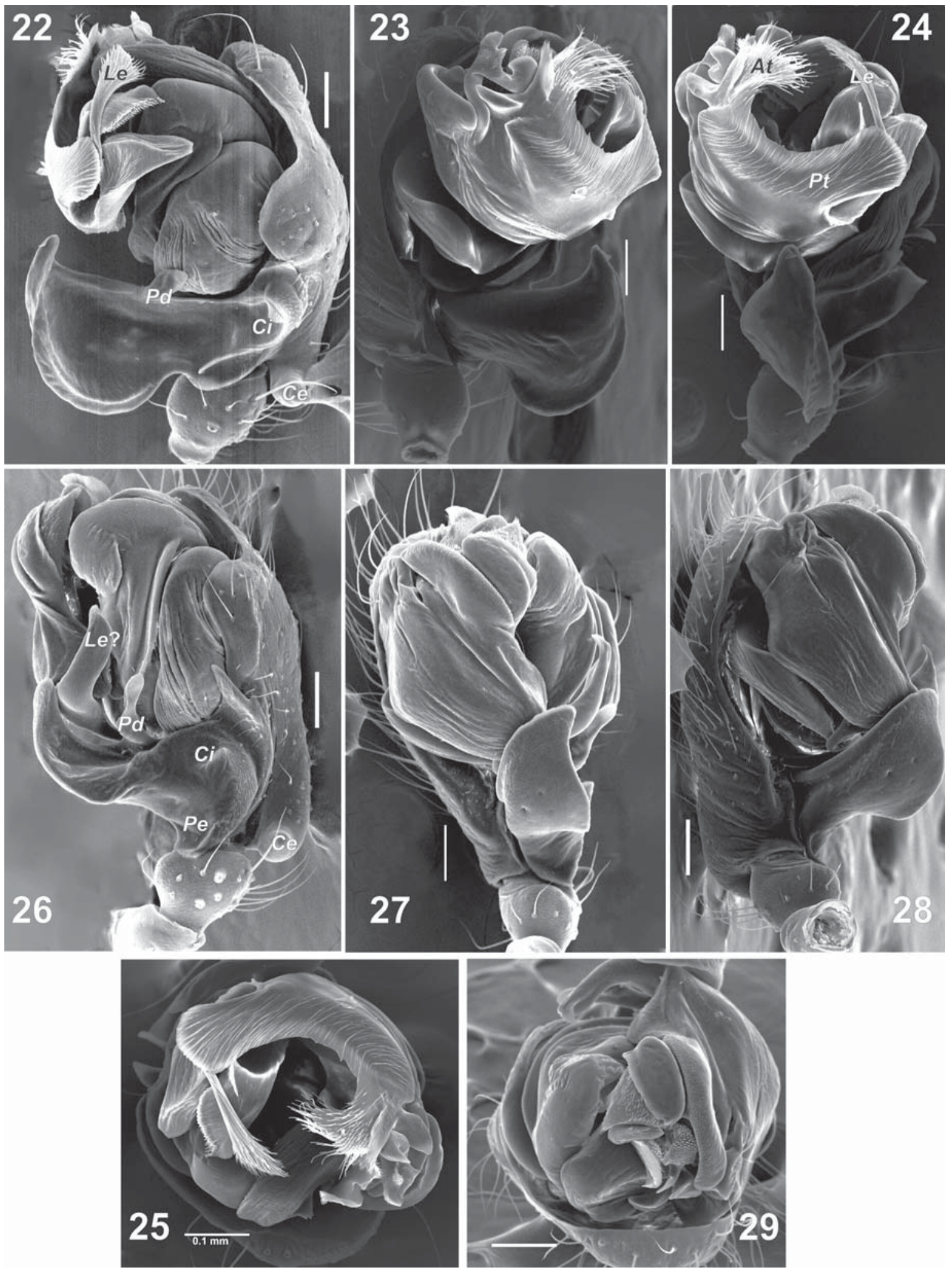

Figs 22-29. SEM micrographs of the male palp of Bifurcia oligerae sp.n. (22-25) and B. tanasevitchi sp.n. (26-29): 22, $26-$ retrolateral; 23, 27 - ventral; 24, 28 - prolateral; 25, 29 - from above. Abbreviations: $C e$ - cymbial apophysis; $C i$ - "cirque-like" pocket of paracymbium; $L e$ - pseudolamella; $P d$ - finger-like anterior extension of paracumbium; $P e$ - a paracymbial posterior extension;

Рис. 22-29. СЭМ микрофотографии пальпы самца Bifurcia oligerae sp.n. (22-25) и B. tanasevitchi sp.n. (26-29): 22, 26 ретролатерально; 23, 27 - вентрально; 24, 28 - пролатерально; 25, 29 - сверху. 
Palp as in Figs 15-18, 26-29. Cymbium with a proximal hook-shaped apophysis. Paracymbium with a small triangular, "cirque-like" pocket, with a relatively large anterior median extension and with a posterobasal paracymbial extension $(P e)$. Lamellar extension of pseudolamella smooth, not barbed.

Female. Total length 2.23, carapace 0.98 long, 0.75 wide. Colouration as in male (Fig. 4). MtI 0.23.

Leg segment length of female:

\begin{tabular}{|l|c|c|c|c|c|c|}
\hline & Femur & Patella & Tibia & Metatarsus & Tarsus & Total \\
\hline I & 1.85 & 0.35 & 1.98 & 1.63 & 0.88 & 6.68 \\
\hline II & 1.75 & 0.33 & 1.58 & 1.48 & 0.85 & 5.98 \\
\hline III & 1.35 & 0.30 & 1.15 & 1.10 & 0.65 & 4.55 \\
\hline IV & 1.70 & 0.30 & 1.55 & 1.38 & 0.80 & 5.73 \\
\hline
\end{tabular}

Epigyne as in Figs 19-21. Scape long, coiled, terminal part held between the posterior median plate (dorsally) and basal weakly sclerotised extension of the septum $(\mathrm{Be})$. The terminal part is widened, with lateral pockets. Posterior median plate rectangular, 3 times longer than wide, about 2 times thinner than terminal part of scape.

DISTRIBUTION AND BIOLOGY. This species is known from the south part of the Maritime Province in the Lazo Reserve. It inhabits stony screes and co-occurs with $B$. oligerae sp.n.

\section{Bifurcia maritima (Tanasevitch, 2010), comb.n.} Figs 10, 14.

Arcuphantes maritimus Tanasevitch, 2010: 271, f. 1-15 ( $0^{7}$ \% $)$ NOTE. This species is well-described by Tanasevitch [2010]. Its range partially overlaps with its sibling, B. oligerae sp.n.

This species is transferred to Bifurcia because it shares the anterior digitiform process of the paracymbium, lacking in Arcuphantes, and lacks the lamella characteristica, which is present in Arcuphantes (see Comments below). While describing Arcuphantes maritimus, Tanasevitch [2010] compared it with B. cucurbitina Zhai et Zhu, 2007.

\section{Comments on the relations of Arcuphantes and related genera}

When Saaristo et al. [2006] diagnosed Bifurcia they did not mention the presence of a character lacking in other Arcuphantes s.l. and in Micronetinae as a whole - the posterior median extension of the paracymbium. Another character that can easily differentiate this genus from Arcuphantes s.str. (A. fragilis Chamberlin et Ivie, 1943, the type species of the genus) is the lack of the lamella charcteristica which is present in $\mathrm{Ar}$ cuphantes (cf. Marusik \& Koponen, 2008: pl. 4; Dupérré, 2013: f. 61). Another character that well distinguishes Arcuphantes s.str. and Bifurcia is the rounded, entire septum, whereas in Arcuphantes s.str., the septum is long and not roundly-bent (cf. Millidge, 1984: f. 82). Tanasevitch [2010] doubted the validity of Bifurcia, however, he did not synonymise the two genera. It seems that he overlooked the figures of the embolic division of Arcuphantes fragilis, the type species of the genus given in Marusik \& Koponen [2008], as well as the figure of epigyne provided by Millidge [1984].

ACKNOWLEDGEMENTS. We thank Tatyana I. Oliger (Russia) for providing the material used in this study. English of the final draft was kindly checked and corrected by Sarah Crews (San Francisco, USA). This work was supported in part by the Far Eastern Federal University (Vladivostok) and by the grant of the President of the Russian Federation (MK-6046.2016.4).

\section{References}

Dupérré N. 2013. Taxonomic revision of the spider genera Agyneta and Tennesseelum (Araneae, Linyphiidae) of North America north of Mexico with a study of the embolic division within Micronetinae sensu Saaristo \& Tanasevitch 1996 // Zootaxa. No.3674. P.1-189.

Marusik Y.M., Koponen S. 2008. Obituary. Michael Ilmari Saaristo (1938-2008) // Arthropoda Selecta. Vol.17. No1-2. P.4-16.

Millidge A.F. 1984. The taxonomy of the Linyphiidae, based chiefly on the epigynal and tracheal characters (Araneae: Linyphiidae) // Bulletin of the British Arachnological Society. Vol.6. Pt.6. P.229-267.

Saaristo M.I., Tu L.H., Li S.Q. 2006. A review of Chinese micronetine species (Araneae: Linyphiidae). Part I: species of exArcuphantes and ex-Centromerus // Animal Biology. Vol.56. No.3. P.383-401.

Tanasevitch A.V. 2010. A new species of Arcuphantes from the Russian Far East, with notes on the genera Fusciphantes and Bifurcia (Arachnida: Aranei: Linyphiidae) // Arthropoda Selecta. Vol.19. No.4. P.269-272.

World Spider Catalog 2016. Available from: http://wsc.nmbe.ch/ (accessed 8 February 2016).

Responsible editor K.G. Mikhailov 